\section{Evaluation of the Transmission of Different Field Sources of Citrus Tristeza Virus and the Separation of Different Genotypes by Single Brown Citrus Aphids}

\author{
Zhipeng Huang \\ Biotechnology Center, College of Life Science and Key Laboratory of \\ Biopesticide and Chemical Biology, Fujian Agriculture and Forestry University, \\ Ministry of Education, Fuzhou, Fujian 350002 P.R. China
}

Phyllis A. Rundell

Indian River Research and Education Center, University of Florida, Fort Pierce, FL 34945

\author{
Xiong Guan \\ Biotechnology Center, College of Life Science and Key Laboratory of \\ Biopesticide and Chemical Biology, Fujian Agriculture and Forestry University, \\ Ministry of Education, Fuzhou, Fujian 350002 P.R. China
}

\author{
Charles A. Powell \\ Indian River Research and Education Center, University of Florida, Fort \\ Pierce, FL 34945
}

Additional index words. diagnosis, the epidemiology of CTV

\begin{abstract}
Four field sources of citrus tristeza virus (CTV) (Y3, Y6, Y7 and Y23) collected from grapefruit trees at groves in Fort Pierce, Florida, and isolate T36were used to evaluate the transmission and separation of different virus genotypes by single brown citrus aphids (BrCA). Analysis of the field sources of CTV by inoculation to indicator plants, ELISA and RT-PCR showed that Y6 was a decline-inducing isolate and Y23 a nondecline-inducing isolate. Assays of genotype by RT-PCR indicated that Y 6 contained the T36 genotype while Y23 contained the T30 genotype. Both $Y 3$ and $Y 7$ were a mixture of decline-inducing and nondecline-inducing CTV isolates and were a mixture of T36 and T30 genotypes. When Y6 and Y23 were the acquisition host for single BrCA, only the T36 or T30 genotypes, respectively, were detected by RT-PCR in 'Mexican' Lime receptor plants. Only the T36 genotype was transmitted to receptor plants from infected Y3 and Y7 plants although these acquisition plants contained more than one genotype. No T3 or VT genotypes were detected in any acquisition or receptor plants. CTV genotype mixtures in the various field sources were separated by single BrCAtransmission and that the T36 genotype in T36/T30 mixtures was more easily transmitted than the T30 genotype when the acquisition plant was 'Duncan' grapefruit and the receptor plant was 'Mexican' lime.
\end{abstract}

Citrus tristeza virus (CTV) is the most economically important citrus virus and is distributed worldwide. Its genome is about 20 kilobases $(\mathrm{kb})$ and contains 12 open reading frames (ORFs) that potentially encode about 19 proteins (Karasev et al., 1995). Aphid transmission and graft inoculation are the two important modes of CTV spread. The virus is transmitted semi-persistently in a noncirculative manner by four aphid species-Aphis gossypii, the cotton or melon aphid (Bar-Joseph et al., 1972); Aphis spiraecola, the spirea aphid (Dickson et al., 1951); Toxoptera aurantii, the black citrus aphid (Normon et al., 1958); and Toxoptera citricida, the brown citrus aphid (Schwarz, 1965). Of these, T. citricida is considered the most efficient vector (RochaPeña et al., 1995). In 1995, T. citricida was

Received for publication 19 Aug. 2004. Accepted for publication 24 Nov. 2004. Florida Agriculture Experiment Station journal series R-10225. discovered in southeastern Florida and it has spread into all major citrus areas of the state. Factors which influence CTV transmission efficiency include the morphological stage of the aphid, the isolate of CTV, acquisition and receptor plants used for CTV transmission, and environmental conditions (Hermoso et al., and Garnsey, 1987).

Serological methods have become an effective tool for detection and differentiation between decline-inducing and nondecline-inducing CTV isolates. They have also played an important role in research on the aphid transmission efficiency of CTV. In recent years, with the available information of CTV genomic sequences, an alternative approach has been developed to discriminate among CTV isolates. This approach is based on the amplification of molecular markers by reverse transcription polymerase chain reaction (RT$\mathrm{PCR}$ ) using primers derived from one or more 1988; Lin et al., 2002; Sharma, 1989; Yokomi regions of the genomes of CTV isolates. The discovery of the single base difference controlling the monoclonal antibody MCA-13 epitope between severe and mild isolates enabled the development of bidirectional PCR with groupspecific primers for the first time to detect both severe (MCA-13 reactive) and mild (MCA-13 nonreactive) isolates in the same plant (Cevik et al., 1996). CTV isolates have been classified into four specific genotypes (T3, T30, T36 and VT) by the amplification of eleven molecular markers using primers derived from analogous regions located in the $5^{\prime}$ half of the genomes of these isolates (Hilf and Garnsey, 2000). Using this technique, two Florida CTV isolates (FS627 and MCN2d) and a Corsican isolate (B192) were used to test the ability of the BrCA to separate the complex of subisolates through single and multiple aphid transmissions from infected sweet orange or 'Mexican' lime to uninfected sweet orange or 'Mexican' lime, and the usefulness of these CTV genotype-specific primers (Brlansky et al., 2003).

In our previous study, six severe and six mild Florida isolates from field sources of CTV were used to evaluate the transmission efficiency of single BrCA to move CTV from infected 'Duncan' grapefruit seedlings (acquisition host) to uninfected 'Mexican' lime seedlings (receptor host). Among these, seven were transmitted successfully although the transmission rate was low (1.5\% on average) (Lin et al., 2002). In this study, RT-PCR was used to examine isolate differentiation of 27 single aphid transmission events from 5 acquisition plants containing CTV that had been graft inoculated from a tree with isolate T36 and from four CTV field sources (Y3, Y6, Y7 and Y23). The purpose of this study was to evaluate at a genetic level the transmission efficiency of using single BrCA for the separation of CTV genotype mixtures when 'Duncan' grapefruit was the acquisition plant and 'Mexican' lime was the receptor plant. The information will help better understand the epidemiology of CTV in grapefruit groves in the Indian River region of Florida, one of the world's major grapefruit producing regions.

\section{Materials and Methods}

Virus sources and transmission by single brown citrus aphids ( $\mathrm{BrCA}$ ). Six CTV sources were used for the transmission of CTV from 'Duncan' grapefruit seedlings (acquisition host) to 'Mexican' lime seedlings (receptor host) by single BrCA. Two sources were the characterized isolates T36 and T30 that were originally obtained from Florida citrus groves by aphid transmission many years ago and have been maintained in the greenhouse at Indian River Research and Education Center in Fort Pierce. Four uncharacterized sources (Y3, Y6, Y7 and Y23) were collected directly from field grapefruit trees at the groves in Fort Pierce, Florida. These CTV sources were grafted into 'Duncan' grapefruit seedlings, and CTV infection was verified by ELISA with CTV monoclonal antibody MAb 17G11. The positively infected plants were used as acquisition plants for single BrCA transmis- 
sion studies. Single virus-free BrCA was used to transmit CTV from acquisition plants to receptor plants-'Mexican' lime seedlings (Lin et al., 2002). Out of 1210 experimental single aphid transmissions, 27 were positive for CTV infection confirmed by ELISA tests with CTV MAb 17G11 and MCA13 when the T36, Y3, Y6, Y7 and Y23 sources were used as acquisition plants. These infected receptor plants, along with the acquisition plants, were assayed by RT-PCR in this study. Stems (about $250 \mathrm{mg}$ ) of mature shoots of citrus plants were used for the extraction of nucleic acid for RT-PCR (Huang et al., 2004). Petioles of the same shoots were used to prepare extractions for ELISA experiments.

Enzyme-linked immunosorbent assay (ELISA). The extracts from petioles of CTVinfected acquisition and receptor plants were used for ELISA tests. Each extract was assayed with three replications. The CTV polyclonal antiserum (PCA) 1212 was used as coating antibody and the other two CTV monoclonal antibodies (MAbs), 17G11 and MCA13, were used as intermediate antibodies. MAb 17G11 cline-inducing isolates of CTV. MAb MCA13 reacts with decline-inducing isolates of CTV from Florida, but not with nondecline-inducing isolates. Positive reactions obtained using Richmond, Calif.) were defined as an $\mathrm{OD}_{415 \mathrm{~nm}}$ 2.5 times higher than the healthy controls.

Nucleic acid extraction and oligonucleotide primers. Total nucleic acid was extracted reacts with both decline-inducing and nondea reader (model 3550; Bio-Rad Laboratories,

as described by Huang et al. (2004) from CTVinfected and healthy stems of acquisition and receptor plants. Two group-specific internal primers developed by Cevik et al. (1996) and two terminal primers for the ends of the capsid protein gene (Huang et al.,2004) were synthesized and used to distinguish the nondecline-inducing and decline-inducing isolates of CTV. Ten other sets of primers - T36POL, T36K17, T36 -5', T30POL, T30K17, T30 -5', VTPOL, VTK17, VT-5' and T3K17 developed by Hilf and Garnsey (2000) were used to further characterize the genotypes of the CTV sources.

cDNA synthesis and PCR amplification. Two PCR analyses were conducted to differentiate the isolate type and to characterize the isolate genotype of CTV. The total reaction volume for the first-strand cDNA synthesis was $20 \mathrm{ul}$, which contained $50 \mathrm{~mm}$ Tris- $\mathrm{HCl}$ (pH8.3), $75 \mathrm{~mm} \mathrm{KCl}, 3 \mathrm{~mm} \mathrm{MgCl}, 10 \mathrm{~mm}$ DTT, $0.5 \mathrm{~mm}$ each of the four dNTPs, 0.75 $\mu \mathrm{M}$ of each primer, 100 units of SuperScript II RNase H- Reverse Transcriptase (Invitrogen, Carlsbad, Calif.), 40 units of RNaseOUT Recombinant Ribonuclease Inhibitor(Invitrogen) and total nucleic acid extract. The contents were mixed gently and incubated at $42{ }^{\circ} \mathrm{C}$ for $50 \mathrm{~min}$. The PCR amplification was performed in $50 \mu \mathrm{L}$ of reaction mixture containing 20 $\mathrm{mm}$ Tris-HCI (pH8.4), $50 \mathrm{~mm} \mathrm{KCl}, 0.2 \mathrm{~mm}$ each of the four dNTPs, $1.5 \mathrm{~mm} \mathrm{MgCl}_{2}, 0.5$ $\mu \mathrm{M}$ of each primer, 2.5 units of Taq DNA polymerase (Invitrogen) and $2.5 \mu \mathrm{L}$ of RT mixture. For the differentiation of isolate type,

Table 1. The transmissions of different CTV sources from 'Duncan' grapefruit to 'Mexican' lime by single BrCA.

\begin{tabular}{|c|c|c|c|c|}
\hline \multirow{2}{*}{$\begin{array}{l}\text { CTV } \\
\text { source }^{2}\end{array}$} & \multirow{2}{*}{$\begin{array}{c}\text { Acquisition } \\
\text { plants }^{y}\end{array}$} & \multicolumn{2}{|c|}{ ELISA of acquisition plants ${ }^{\mathrm{x}}$} & \multirow{2}{*}{$\begin{array}{c}\text { Transmission } \\
\text { rate }^{\mathrm{w}}\end{array}$} \\
\hline & & $17 \mathrm{G} 11$ & MCA13 & \\
\hline T30 & DGT30 & + & - & $0 \%(0 / 180)$ \\
\hline T36 & DGT36 & + & + & $2.0 \%(7 / 360)$ \\
\hline Y3 & DGY3 & + & + & $2.4 \%(7 / 290)$ \\
\hline Y6 & DGY6 & + & + & $3.5 \%(6 / 170)$ \\
\hline Y7 & DGY7 & + & + & $3.6 \%(4 / 110)$ \\
\hline Y23 & DGY23 & + & - & $3.0 \%(3 / 100)$ \\
\hline $\mathrm{H}$ & $\mathrm{H}$ & - & - & $0 \%(0 / 50)$ \\
\hline
\end{tabular}

${ }^{2}$ T30 is a nondecline-inducing isolate of CTV. T36 is a decline-inducing isolate of CTV. Y3, Y6, Y7, and Y23 are four field sources of CTV collected from grapefruit trees at groves in Indian River Research and Education Center, Fort Pierce,Fla. H is a uninfected control.

'The CTV sources were grafted into 'Duncan' grapefruit seedlings and the CTV-positive seedlings were used as acquisition plants for single BrCA transmission. For example, DGT30 is the 'Duncan' grapefruit seedlings grafted with inoculum from plant infected by T30.

${ }^{\mathrm{x}} 17 \mathrm{G} 11$ reacts with both decline-inducing and nondecline-inducing CTV isolates. MCA13 reacts with Florida decline-inducing CTV isolates, but not with nondecline-inducing CTV isolates; $(+)$ positive reaction, (-) negative reaction.

${ }^{\text {w}}$ Data inside the parenthesis indicated number of CTV-positive plants/no. inoculated plants.
PCR cycling profiles were one cycle at $94^{\circ} \mathrm{C}$ for $10 \mathrm{~min}, 35$ cycles at $94{ }^{\circ} \mathrm{C} 1 \mathrm{~min}, 50{ }^{\circ} \mathrm{C} 2$ min and $72{ }^{\circ} \mathrm{C} 2 \mathrm{~min}$, with a final extension step at $72{ }^{\circ} \mathrm{C}$ for $20 \mathrm{~min}$. For the analysis of isolate genotype, PCR was performed using the following cycling profiles - one cycle at $94{ }^{\circ} \mathrm{C}$ for $5 \mathrm{~min}, 35$ cycles at $94{ }^{\circ} \mathrm{C} 30 \mathrm{~s}, 56$ ${ }^{\circ} \mathrm{C} 30 \mathrm{~s}$ and $72{ }^{\circ} \mathrm{C} 45 \mathrm{~s}$, followed by a final extension step at $72{ }^{\circ} \mathrm{C}$ for $10 \mathrm{~min}$. Aliquots of PCR products were electrophoresed in $2 \%$ agarose gels in Tris-borate (TBE) buffer (0.09 M Tris base, $0.09 \mathrm{M}$ boric acid, $0.002 \mathrm{M}$ EDTA, pH8.0). After electrophoresis, the gels were stained with $0.5 \mu \mathrm{g} \cdot \mathrm{mL}^{-1}$ of ethidium bromide and analyzed with BIO imaging system (Syngene, Frederick, Md.). A 100-bp DNA Ladder (Promega, Madison, Wis.) was used as a nucleic acid marker.

\section{Results}

Single aphid transmissions and ELISA. All the acquisition plants and 27 of 1210 aphid transmission receptor plants were positive for CTV by ELISA with MAb 17G11 (Table 1). The T30 and Y23 acquisition plants were negative using MAb MCA13 which corresponds to its nondecline-inducing phenotype. No aphid transmissions were achieved from the T30 acquisition plant. The T36, Y3, Y6 and $\mathrm{Y} 7$ acquisition plants and all positive receptor plants also reacted with MAb MCA13 indicating the presence of decline-inducing CTV isolate (Tables 1-4). The Y23 aphid transmission receptor plants did not react with MAb MCA13 (Table 5).

Differentiation of CTV isolates type. RTPCR was conducted with four primers to characterize the isolate type (decline or nondecline inducing) of CTV in 5 acquisition and 27 receptor plants by single aphid transmission (Fig. 1). Decline-inducing isolate T36, nondecline-inducing isolate T30 and a healthy sample were used as positive and negative controls. The 672 bp and 392 bp products were amplified from both the Y23 acquisition plant and its single aphid transmission receptor plants, indicating that they were infected only with nondecline-inducing isolates of CTV (Fig. 1, lane 5 to 7). From both acquisition and single aphid transmission receptor plants of Y6 and T36, the $672 \mathrm{bp}$ and $320 \mathrm{bp}$ products were produced, indicating that they were infected only with decline-inducing isolates of CTV (Fig. 1, lanes 22 to 30). From the Y3 and Y7 acquisition plants, the 672-, 392-, and 320-bp

Table 2. The molecular markers profiles of Y3 in acquisition and receptor plants.

\begin{tabular}{|c|c|c|c|c|c|c|c|c|c|c|c|c|}
\hline \multirow{2}{*}{$\begin{array}{l}\text { CTV } \\
\text { source }\end{array}$} & \multicolumn{11}{|c|}{ RT-PCR markers ${ }^{y}$} & \multirow[b]{2}{*}{ Genotype } \\
\hline & MCA13 & T36POL & T36K17 & T36-5' & T30POL & T30K17 & T30-5' & VTPOL & VTK17 & VT-5' & T3K17 & \\
\hline$\overline{\mathrm{DGY} 3}$ & + & + & + & + & + & + & + & - & + & + & - & T36, T30 \\
\hline AY3-1 & + & + & + & + & - & - & - & - & - & - & - & T36 \\
\hline AY3-40 & + & + & + & + & - & - & - & - & - & - & - & T36 \\
\hline AY3-46 & + & + & + & + & - & - & - & - & - & - & - & T36 \\
\hline AY3-48 & + & + & + & + & - & - & - & - & - & - & - & T36 \\
\hline AY3-86 & + & + & + & + & - & - & - & - & - & - & - & T36 \\
\hline
\end{tabular}

${ }^{2}$ DGY3 is the acquisition plant of Y3. AY3-1, 11, 40, 46, 48, 86, and 93 were the CTV-positive receptor plants transmitted from DGY3 by single BrCA. ${ }^{y}$ Each molecular marker is amplified with the corresponding primer respectively. For example, T36POL marker is amplified with primer T36POL; $(+)$ positive band, (-) no band. 
Table 3. The molecular markers profiles of Y6 in acquisition and receptor plants.

\begin{tabular}{|c|c|c|c|c|c|c|c|c|c|c|c|c|}
\hline \multirow{2}{*}{$\begin{array}{l}\text { CTV } \\
\text { source }^{z}\end{array}$} & \multicolumn{11}{|c|}{ RT-PCR markers ${ }^{y}$} & \multirow[b]{2}{*}{ Genotype } \\
\hline & MCA13 & T36POL & T36K17 & T36-5' & T30POL & T30K17 & T30-5' & VTPOL & VTK17 & VT-5' & T3K17 & \\
\hline$\overline{\text { DGY6 }}$ & + & + & + & + & - & - & - & - & - & - & - & T36 \\
\hline AY 6-4 & + & + & + & + & - & - & - & - & - & - & - & T36 \\
\hline AY6-6 & + & + & + & + & - & - & - & - & - & - & - & T36 \\
\hline AY6-8 & + & + & + & + & - & - & - & - & - & - & - & T36 \\
\hline AY6-42 & + & + & + & + & - & - & - & - & - & - & - & T36 \\
\hline AY6-47 & + & + & + & + & - & - & - & - & - & - & - & T36 \\
\hline AY6-48 & + & + & + & + & - & - & - & - & - & - & - & T36 \\
\hline
\end{tabular}

${ }^{2}$ DGY6 is the acquisition plant of Y6. AY6-4, 6, 8, 42, 47, and 48 were the CTV-positive receptor plants transmitted from DGY6 by single BrCA.

${ }^{y}$ Each molecular marker is amplified with the corresponding primer respectively. For example, T36POL marker is amplified with primer T36POL; $(+)$ positive band, (-) no band.

Table 4. The molecular markers profiles of Y7 in acquisition and receptor plants

\begin{tabular}{|c|c|c|c|c|c|c|c|c|c|c|c|c|}
\hline \multirow{2}{*}{$\begin{array}{l}\text { CTV } \\
\text { source }^{z}\end{array}$} & \multicolumn{11}{|c|}{ RT-PCR markers ${ }^{y}$} & \multirow[b]{2}{*}{ Genotype } \\
\hline & MCA13 & T36POL & T36K17 & T36-5' & T30POL & T30K17 & T30-5' & VTPOL & VTK17 & VT-5' & $\mathrm{T} 3 \mathrm{~K} 17$ & \\
\hline$\overline{\mathrm{DGY} 7}$ & + & + & + & + & + & + & - & - & + & - & - & T36, T30 \\
\hline AY7-65 & + & + & + & + & - & - & - & - & - & - & - & T36 \\
\hline AY7-80 & + & + & + & + & - & - & - & - & - & - & - & T36 \\
\hline AY7-101 & + & + & + & + & - & - & - & - & - & - & - & T36 \\
\hline AY7-102 & + & + & + & + & - & - & - & - & - & - & - & T36 \\
\hline
\end{tabular}

${ }^{2}$ DGY7 is the acquisition plant of Y7. AY7-65, 80, 101, 102 were the CTV-positive receptor plants transmitted from DGY7 by single BrCA.

${ }^{\mathrm{y}}$ Each molecular marker is amplified with the corresponding primer respectively. For example, T36POL marker is amplified with primer T36POL; $(+)$ positive band, (-) no band.

Table 5. The molecular markers profiles of Y23 in acquisition and receptor plants.

\begin{tabular}{|c|c|c|c|c|c|c|c|c|c|c|c|c|}
\hline \multirow{2}{*}{$\begin{array}{l}\text { CTV } \\
\text { source }^{z}\end{array}$} & \multicolumn{11}{|c|}{ RT-PCR markers ${ }^{y}$} & \multirow[b]{2}{*}{ Genotype } \\
\hline & MCA13 & T36POL & T36K17 & T36-5' & T30POL & T30K17 & T30-5' & VTPOL & VTK17 & VT-5' & $\mathrm{T} 3 \mathrm{~K} 17$ & \\
\hline$\overline{\mathrm{DGY}} 23$ & - & - & - & + & + & + & + & - & + & + & - & T30 \\
\hline AY23-30 & - & - & - & - & + & + & + & - & + & + & - & T30 \\
\hline AY23-35 & - & - & - & - & + & + & - & - & + & - & - & $\mathrm{T} 30$ \\
\hline AY23-39 & - & - & - & - & + & + & + & - & - & + & - & T30 \\
\hline
\end{tabular}

${ }^{2}$ DGY23 is the acquisition plant of Y23. AY23-30,35,39 were the CTV-positive receptor plants transmitted from DGY23 by single BrCA.

${ }^{y}$ Each molecular marker is amplified with the corresponding primer respectively. For example, T36POL marker is amplified with primer T36POL; $(+)$ positive band, (-) no band.

123456789101112131415161718192021222324252627282930

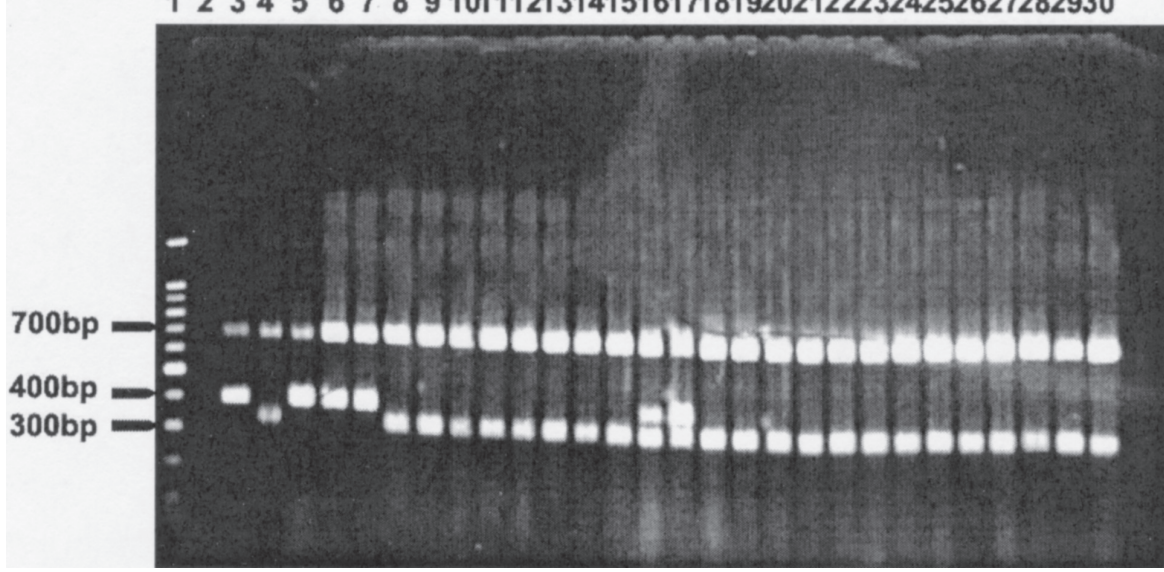

Fig. 1. Analysis of RT-PCR products amplified with group-specific primers. Lane 1 = 100-bp DNA ladder; lane 2 = extract of healthy plant; lane 3 = T30; lane 4 = T36; lane $5=$ DGY23; lane 6=AY23-35; lane 7 =AY23-39; lane 8=AY3-1; lane 9=AY3-11; lane10 =AY3-40; lane $11=\mathrm{AY3}-40 \mathrm{D} 1$; lane $12=\mathrm{AY} 3$ 46; lane 13 = AY3-48; lane 14 = AY3-86; lane 15 = AY3-93; lane 16= DGY3; lane 17 = DGY7; lane 18 =AY7-65; lane 19=AY7-80; lane 20 = AY7-101; lane $21=$ AY7-102; lane 22 = DGY6; lane $23=$ AY6-4; lane 24 =AY6-6; lane 25=AY6-8; lane 26=AY6-42; lane 27=AY6-47; lane 28=AY6-48; lane $29=$ DGT36; lane $30=$ AT36-80. ${ }^{\text {z} D G Y 23 ~ i s ~ t h e ~ a c q u i s i t i o n ~ p l a n t ~ o f ~ Y 23 ~ A Y 23-35 ~ a n d ~ A Y 23-39 ~ a r e ~}$ CTV-positive receptor plants transmitted from DGY23 by single BrCA. ${ }^{\mathrm{y}} \mathrm{DGY} 3$ is the acquisition plant of 3 AY3-1, 11, 40, 40D1, 46, 48, 86, 93 are CTV-positive receptor plants transmitted from DGY3 by single BrCA. ${ }^{\mathrm{D}} \mathrm{DGY} 7$ is the acquisition plant of 7 AY7-65,80,101,102 are CTV-positive receptor plants transmitted from DGY7 by single BrCA. ${ }^{\text {D DGY6 }}$ is the acquisition plant of Y6 AY 6-4,6,8,42,47,48 are CTV-positive receptor plants transmitted from DGY6 by single BrCA. "DGT36 is the acquisition plant of T36 AT36-80 CTV-positive receptor plants transmitted from DGT36 by single BrCA. products were all produced, indicating that they were infected with both decline-inducing and nondecline-inducing isolates of CTV (Fig. 1, lanes 16 and 17). However, only the 672- and 320-bp products were amplified from the Y3 and Y7 single aphid transmission receptor plants, indicating that they were infected only with decline-inducing isolate of CTV (Fig. 1 , lanes 8 to 15 and 18 to 21$)$. No product was observed from the healthy tissue extract (Fig. 1, lane 2).

Analysis of isolate genotype of CTV. The genotypes of isolate T36 and field sources Y3, Y6, Y7, and Y23 in both acquisition and single aphid transmission receptor plants were analyzed by using ten sets of primers - T36POL, T36K17, T36-5', T30POL, T30K17, T30 -5', VTPOL, VTK17, VT-5', and T3K17. Based on the appearance of multiple molecular markers, the isolates can be classified into four genotypes (T3, T30, T36, or VT). The T30, T36, and VT genotypes were designated if products occurred with T30POL, T36POL, and VTPOL markers, respectively. ForY3 and Y7, the mixture of T36 and T30genotypes appeared in their acquisition plants, but only the T36 genotype was detected in the single aphid transmission receptor plants (Tables 2 and 4). The acquisition and single aphid transmission receptor plants of T36 and Y6 were shown to contain the T36 genotype 
alone and their molecular markers were the same (data of T36 not shown, Table 3). Only the T30genotype was found in both acquisition and single aphid transmission receptor plants of Y23, however, there is a small difference in the molecular markers (Table 5). No T3 or VT genotype was found in any samples.

\section{Discussion}

Since the characterization and classification of many field sources ofCTV by the comparison of genome sequences was impractical, an alternative method has been developed to classify CTV isolates using ten sets of primers derived from three regions (5', K17 and POL) of the genomes of isolates T30, T36, T3, and VT (Hilf and Garnsey, 2000). Analysis of isolates collected from commercial and dooryard sites throughout the state of Florida during the 19931998 period indicated that the T30and T36 were the primary genotypes in commercial trees, the VT genotype was not detected in commercial sweet orange or grapefruit plantings and the T3 genotype was not detected in commercial trees (Hilf and Garnsey, 2003). The assay of four field sources of CTV collected from grapefruit groves in Fort Pierce, Florida and their transmission by single BrCAalso showed that only the T30 and T36 genotypes appeared in both acquisition and receptor plants, and the T3 or VT genotype was not detected (Tables $2-5)$. In order to acquire more evidence, we have recently analyzed the isolate genotypes in other grapefruit trees in the Indian River region which were CTV-positive by DTBIA and ELISA using CTV MAb 17G11 and MCA13, and have not found the T3 or VT genotype (data not shown). Thus, CTV field isolates in grapefruit in our location are primarily T30and T36 isolates and that T3 and VT isolates are not prevalent at our collection sites.

The BrCA has been widely considered the most efficient vector of CTV, but our previous results have shown that it is an inefficient vector when the acquisition plant is 'Duncan' grapefruit and the receptor plant is 'Mexican' lime. The transmission rates of isolates T30 and T36, and field sources Y3, Y6, Y7, and Y23 by single BrCA were $0.0 \%, 2.0 \%, 2.4 \%$, $3.5 \%, 3.6 \%$, and $3.0 \%$ respectively (Table 1 ). In this study, we evaluated their transmission and separation by single BrCA based on the analysis of isolate type and genotype of CTV. The results indicated that they are separated selectively by single BrCA transmission.
These results are somewhat different from that reported by Brlansky et al. (2003). According to their results, when the acquisition and receptor plants were sweet orange or 'Mexican' lime, the composition of the isolate genotypes detected in the receptor plants was different from the isolates within acquisition plants from which they were transmitted by single and multiple BrCA. Therefore, a genotype which was not found in the acquisition plant sometimes appeared in a receptor plant after aphid transmission (Brlansky et al., 2003). We have also found that virus isolates, not detected by immunological methods, can be graft-inoculated (Powell et al., 2003) or single aphid transmitted (Powell et al., 2005) from isolate mixtures. However, we have not observed this phenomenon when using a PCR-based detection protocol. The difference is likely due to virus acquisition plant selection.

Isolates of CTV are known to differ in their ability to be transmitted by aphids. Some isolates are relatively easily transmitted whereas others are very difficult to be transmitted. A field citrus tree can contain several CTV isolates that differ in their aphid transmissibilities (Raccah et al., 1980). We found in this study that the T36 genotype, when it is present in a mixed infection with T30 genotype, is more easily transmitted than T30 (Tables 2 and 4). The factors that effect transmissibility of CTV are still uncertain although the population and morphological stage of the aphid, the isolate of CTV, the acquisition and receptor plants used for aphid transmission, and environmental conditions are probably all involved. More research on the molecular mechanism of aphid-isolate-plant interactions need to be further conducted to unravel the complexities of CTV aphid transmissibility.

\section{Literature Cited}

Bar-Joseph, M. and G. Loebenstein. 1972. Effects of strain source plant, and temperature on transmissibility of citrus tristeza virus by the melon aphid. Phytopathology 63:716-720.

Brlansky, R.H., V.D. Damseegt, D.S. Howd, and A. Roy. 2003. Molecular analyses of citrus tristeza virus subisolates separated by aphid transmission. Plant Dis. 87:397-401.

Cevik, B., S.S. Pappu, H.R. Pappu, D. Benscher, M. Irey, R.F. Lee, and C.L. Niblett. 1996. Application of bidirectional PCR to citrus tristeza virus: Detection and strain differentiation, p. 17-24. In: Proc. Conf. IOCV, 13th IOCV, Riverside, Calif.

Dickson, R.C., R.A. Flock, and M.McD. Johnson.
1951. Insect transmission of citrus quick decline virus. J. Econ. Entomol. 44:172-176.

Hermoso de Mendoza, A., J.F. Ballester-Olmos, J.A. Piña Lorca, J. Serra, and C. Fuertes. 1988. Differences in transmission and efficiency of citrus tristeza virus by Aphis gossypii using sweet orange, mandarin or lemon trees as donor or receptor host plants, p. 63-64. In: Proc. Conf. IOCV, 14th IOCV, Riverside, Calif.

Hilf, M.E., and S.M. Garnsey. 2000. Characterization and classification of citrus tristeza virus isolates by amplification of multiple molecular markers, p. 18-27. In: Proc. Conf. IOCV, 14th IOCV, Riverside, Calif.

Hilf, M.E., and S.M. Garnsey. 2003. Citrus tristeza virus in Florida: A synthesis of historical and contemporary biological, serological and genetic data. In: Proc. Conf. IOCV, 17th IOCV, Riverside, Calif.

Huang, Z.P., P.A. Rundell, X. Guang, and C.A. Powell. 2004. Detection and isolate differentiation of citrus tristeza virus in infected field trees based on reverse transcription-polymerase chain reaction. Plant Dis. 88:625-629.

Karasev,A.V., V.P.Boyko, S.Gowda, Q.V.Nikolaeva, M.E. Hilf, E.V. Koonin, C.L. Niblett, K. Cline, D.J. Gumpf, R.F. Lee, S.M. Garnsey, D.J. Lewandowski, and W.O.Dawson. 1995. Complete sequence of the citrus tristeza virus RNAgenome. Virology 208:511-520.

Lin, Y.J., R.H. Brlansky, and C.A. Powell. 2002. Inefficient transmission of citrus tristeza virus from grapefruit by single brown citrus aphids. HortScience 37:936-939.

Norman, P.A., and T.J. Grant. 1958. Transmission of tristeza by aphids in Florida. Proc. Fla. State Hort. Soc. 69:38-42.

Powell,C.A., P.A. Rundell, and R.R. Pelosi. 2003. Suppression of decline-inducing isolate of citrus tristeza virus by nondecline-inducing isolates. HortScience 38:62-64.

Raccah, B., G. Loebenstein, and S. Singer. 1980. Aphid-transmissibility variants of citrus tristeza virus in infected citrus trees. Phytopathology 70:89-93.

Rocha-Peña, M.A., R.F. Lee, R. Lastra, C.L. Niblett, F.M.Ochoa-Corona, S.M. Garnsey, and R.K. Yokomi. 1995. Citrus tristeza virus and its aphid vector Toxoptera citricida. Plant Dis. 79:437-445.

Schwarz, R.E. 1965. Aphid-borne virus diseases of citrus and their vectors in South Africa. B. Flight activity of citrus aphids. S. Afr. J. Agr. Sci. 8:931-940.

Sharma, S.R. 1989. Factors affecting vector transmission of citrus tristeza Virus disease in south Africa. Zentralblatt fur Microbiologie 144:283-294.

Yokomi, R.K. and S.M. Garnsey. 1987. Transmission of citrus tristeza virus by aphis gossypii and aphis citricola in Florida. Phytophylactica 19:169-172. 